\begin{tabular}{|l|l|l||}
\hline \multicolumn{2}{|c|}{ PublisherInfo } \\
\hline \hline PublisherName & $:$ & BioMed Central \\
\hline \hline PublisherLocation & $:$ & London \\
\hline \hline PublisherImprintName & $:$ & BioMed Central \\
\hline \hline
\end{tabular}

\title{
Politicizing research or responsible oversight?
}

\begin{tabular}{|l|l|l||}
\hline \multicolumn{2}{|c|}{ ArticleInfo } \\
\hline \hline ArticleID & $:$ & 4811 \\
\hline \hline ArticleDOI & $:$ & $10.1186 /$ gb-spotlight-20030714-01 \\
\hline \hline ArticleCitationID & $:$ & spotlight-20030714-01 \\
\hline \hline ArticleSequenceNumber & $:$ & 163 \\
\hline \hline ArticleCategory & $:$ & Research news \\
\hline ArticleFirstPage & $:$ & 1 \\
\hline \hline ArticleLastPage & $:$ & 4 \\
\hline \hline & & RegistrationDate : 2003-7-14 \\
\hline ArticleHistory & $:$ & OnlineDate \\
\hline \hline ArticleCopyright & $:$ & BioMed Central Ltd2003-7-14 \\
\hline \hline ArticleGrants & $:$ & \\
\hline \hline ArticleContext & $:$ & 130594411 \\
\hline \hline
\end{tabular}


Ted Agres

Email: tedagres@lycos.com

WASHINGTON, D.C. - Professional scientific societies are dismayed that an amendment to rescind funding for five peer-reviewed National Institutes of Health (NIH) research grants was defeated on the House floor by only two votes last week. The proposed amendment, authored by Rep. Patrick Toomey (R-Penn.), was introduced July 10 during floor debate on the House fiscal year (FY) 2004 appropriations bill(HR 2660), which includes funding for NIH.

The amendment would have defunded research for four NIH grants studying human sexual behavior and one grant investigating human linkages with a panda reserve in China. The measure was defeated 210 to 212 .

Howard J. Silver, executive director for the Consortium of Social Science Associations(COSSA), a Washington, D.C.-based advocacy group representing more than 100 professional organizations in the social sciences, was surprised and worried that the amendment had gathered so many affirmative votes.

"It's a little precarious," he said. "You've got a situation where you combine the questioning of peer review with grants on studies viewed by some as illegitimate for federal funding, such as research on sexuality. Peer review has been sacrosanct for the scientific community, but it has not been all that sacrosanct for members of Congress and politicians."

"It was absolutely surprising and shocking," added Howard Garrison, public affairs director for the Federation of American Societies for Experimental Biology (FASEB). "It came up so quickly that our leadership hadn't even had a chance to consider it."

Toomey's amendment would have instructed NIH to shut off and redirect funds for four sexual behavior studies: a study on San Francisco's Asian prostitutes and masseuses, a study of sexual habits of older men, a study on mood arousal and sexual risk taking, and a study on American Indian and Alaskan transgendered individuals. The four grants total around \$1.5 million in FY 2004.

"Who thinks this stuff up?" Toomey asked his colleagues on the House floor last week. "And worse, who decides to actually fund these sorts of things? Well, unfortunately, the NIH has done so." The Pennsylvania republican was careful to call these particular grants exceptions to the generally meaningful biomedical research that NIH sponsors. "There are so many far more important, very real diseases that are affecting real people," he said. "And that is what this kind of money could be used for, would be used for."

His amendment sparked a heated debate over the value of scientific research and the merits of peer review. Rep. Chris Chocola (R-Ind.) and Rep. Jeff Flake (R-Ariz.) concurred with Toomey's criticism.

"Although the peer review process is probably pretty good, there comes a time when you have to say no, when you have to say this money is not spent in the best interests of the American people," Chocola said. Flake added, "The question we need to have answered is not whether this is scientifically based or reviewed, but is it proper for the taxpayers to fund." 
But Rep. Randy "Duke" Cunningham (R-Calif.), said that he "reluctantly opposed" the amendment because second-guessing NIH research funding would set a bad precedent. "I personally believe that things and discoveries should be left up to NIH," he said. "In the past, many of the diseases were politicized and funding was totally taken away from others, and I want to stay away from that."

Members of the appropriations committee, which passed the FY 2004 Labor, Health and Human Services, Education, and Related Agencies funding measure, spoke against the amendment. Rep. Ralph Regula (R-Ohio), chairman of the House Labor, Health and Human Services Appropriations Subcommittee, agreed "it would set a dangerous precedent and put a chill on medical research if we start to micromanage individual NIH grants."

Regula invited legislators to forward any concerns they might have about specific NIH issues to the House Committee on Energy and Commerce, which he said "has been doing an extensive review of NIH actions across a number of areas" in preparation for reauthorization hearings. Rep. C.W. Bill Young (RFla.), chairman of the Appropriations Committee, agreed and called Toomey's effort "a mischievous amendment" that should be defeated.

Rep. David Obey (D-Wis.), ranking democrat on the appropriations committee, recalled how years ago his former democratic colleague, Sen. William Proxmire, created the "Golden Fleece Awards" to ridicule scientific research studies that appeared to be worthless wastes of government funding. "One year he made a whole lot of fun of a study on Polish pigs. They had a field day with it - funny name, strange-sounding grant. Well, guess what? That study led to the development of a new blood pressure medicine which millions of people use today," Obey said.

"The one thing I came to understand very quickly is that the day that we politicize NIH research... is the day we will ruin science research in this country. We have no business making political judgments about those kinds of issues," he said.

When the roll call vote was taken, however, 177 republicans and 33 democrats voted in favor of the amendment to shut down the sexual behavior research grants, while 165 democrats, 46 republicans, and 1 independent voted to defeat the measure.

Following action on this and other amendments, the House voted 215 to 208 to approve the overall Labor, Health and Human Services funding measure, which would give NIH \$27.66 billion for the FY 2004 that begins October 1. The amount matches the White House's budget request and is a 2.5\% increase over this year.

On June 25, the Senate Labor, Health and Human Services, Education, and Related Agencies Subcommittee allocated $\$ 27.98$ billion to $\mathrm{NIH}$, a 3.7\% increase of $\$ 1.0$ billion over this year's appropriation and $\$ 318.6$ million more than the White House requested. Senate floor action is hoped for before the August recess.

COSSA's Howard Silver likened Toomey's amendment to efforts by some in Congress to earmark federal grants to specific institutions or individuals. "The scientific community has done a good job of keeping the kind of earmarking you see in education and agriculture out of NIH and NSF," he said. "But it's always sort of like keeping your finger in the dike and water is rushing out at you." 
But Toomey viewed his proposed amendment as an exercise in responsibility. "We have an affirmative obligation... to supervise and provide oversight. And when a bureaucracy is making mistakes, we have an obligation to come here and correct that. That is all we are saying."

\section{References}

1. Agres T: Budget wrangling begins The Scientist, June 27, 2003., [http://www.the-scientist.com/news/ 20030627/03/]

2. Consortium of Social Science Associations, [http://www.cossa.org/]

3. Federation of American Societies for Experimental Biology, [http://www.faseb.org/]

4. Irion RW: What Proxmire's golden fleece did for - and to - science... The Scientist, 2:17, December 12, 1988., [http://www.the-scientist.com/yr1988/dec/prof_881212.html] 